\title{
Graduated recession of the superior oblique muscle
}

\author{
JORGE ALBERTO F. CALDEIRA \\ From the Ophthalmological Clinic, Faculty of Medicine, University of São Paulo, Brazil
}

Tenotomy or tenectomy is at present the most usual procedure for diminishing the action of the superior oblique muscle (SO). Hughes and Bogart (1942) described the recession of the trochlea but this procedure has not been generally accepted.

Foster (1946) performed a recession of the SO after temporary division of the superior rectus with a reasonably good result, but his technique was apparently not tried by other ophthalmic surgeons. Fink (1962), in his book on surgery of the vertical muscles, considered tenotomy to be the most satisfactory operation for reducing the effect of an overactive SO.

Ciancia and Prieto-Diaz (1970) described a recession of the $\mathrm{SO}$ without severing the superior rectus and reported on 12 patients with an $A$ phenomenon submitted to bilateral surgery. The amount of recession was the same in all patients.

Duke-Elder and Wybar (1973) mentioned recession of the SO when dealing with techniques but not in reference to treatment of the A phenomenon.

Stanworth (1968) commented on the difficulty of having to re-attach the SO tendon but concluded that this could be done securely.

Overaction of the SO can be bilateral, as seen in some patients with horizontal strabismus and an A phenomenon. It can, however, be unilateral, as observed in some cases with a vertical deviation in the primary position. In both situations a weakening procedure of the SO, either bilateral or unilateral, may be the surgery of choice.

The purpose of this paper is first, to describe a technique which allows a graduated recession of the SO; and secondly, to evaluate the results so obtained in cases of A phenomenon or vertical strabismus.

\section{Patients and methods}

An overactive SO was recessed consecutively in 28 eyes of 16 patients. In 12 cases there was an A phenomenon and in four a vertical imbalance in the primary position.

The A phenomenon varied from 14 to 47 prism

Address for reprints: Jorge Alberto F. Caldeira, MD, Rua Amália Noronha, 289, 05410 São Paulo, SP, Brazil dioptres (average 27). Of the four patients with vertical deviation in the primary position it measured 10 PD in two patients, 12 in one, and 14 in the fourth.

Of the 12 cases with A phenomenon, only one had exotropia and the surgery comprised bilateral recession of the SO; the remaining I I subjects had an A esotropia and besides bilateral recession of the $\mathrm{SO}$ a unilateral recession-resection procedure was used for the horizontal deviation. Of the 12 bilateral recessions, in nine the degree was the same in both eyes; in the remaining three it was different, either because there was an associated slight vertical deviation in the primary position or some vertical incomitancy between dextroversion and laevoversion.

Of the four cases with vertical deviation two had esotropia and a recession-resection of the horizontal rectus muscles preceded the recession of the SO in the same eye; the third patient had a minimal intermittent esotropia in the primary position and only the SO was recessed; the fourth subject had exotropia and surgery consisted of recession of the SO in one eye and of the lateral rectus in the other (Table).

Eleven patients were from the University Hospital and five from private practice. All were Caucasians (seven boys and nine girls) and their ages ranged from 4 years and 2 months to 17 years and 10 months (mean 9 years).

All patients were examined and evaluated by the author before and after surgery. The prism-and-cover measurements were obtained, with glasses if the patient wore them, at $5 \mathrm{~m}$ and $33 \mathrm{~cm}$. For distance the measurements were made in the primary position, supraversion, and infraversion.

In examining the binocular rotations the patient was encouraged to make extreme efforts (Jampolsky, 197I). The rotations were graded from $+\mathrm{I}$ to +4 and from $-I$ to -4 . The horizontal rotations were graded as described by Caldeira (1975a).

All patients were operated on under general anaesthesia. The recessions of the SO, which varied from 8 to $12 \mathrm{~mm}$, were all performed by the author. Surgery of the horizontal rectus muscles was done either by the author or by a house surgeon.

The surgical technique is as follows. The approach to the SO is similar to that described by Caldeira (1975b) for resection of the muscle.

I. A 4-O silk traction suture is placed at 12 o'clock on the limbus and secured to the surgical drape so that the eye is turned downwards.

2. The bulbar conjunctiva is incised over the insertion of the superior rectus and beyond both its extremities. 
3. Tenon's capsule is opened with scissors between two toothed forceps, temporally and medially to the superior rectus, and an incision is made parallel to both margins of the muscle.

4. A $4-0$ silk traction suture is placed beneath the superior rectus and attached to the surgical drape so that the eye is turned strongly downwards and nasally.

5. The belly of the superior rectus is displaced nasally with a Fink retractor and isolated from the underlying structures. The tendon of the SO is exposed to direct vision either at once or after careful dissection of the fascial tissues.

6. A muscle hook is passed back along the sclera and under the tendon of the SO; the point is brought laterally forwards and the tendon engaged.

7. The anterior and posterior ends of the insertion are marked with a needle containing methylene blue.

8. A 4-0 double-armed plain catgut suture is inserted through the tendon and its fascial sheath near the insertion and secured at both margins.

9. The tendon and sheath are severed laterally to the suture (Fig. I) and slipped beneath the superior rectus, showing through the incision previously made in Tenon's capsule nasally to the muscle.

10. With methylene blue a point is marked on the sclera $2.5 \mathrm{~mm}$ behind the medial edge of the superior rectus insertion. This point corresponds

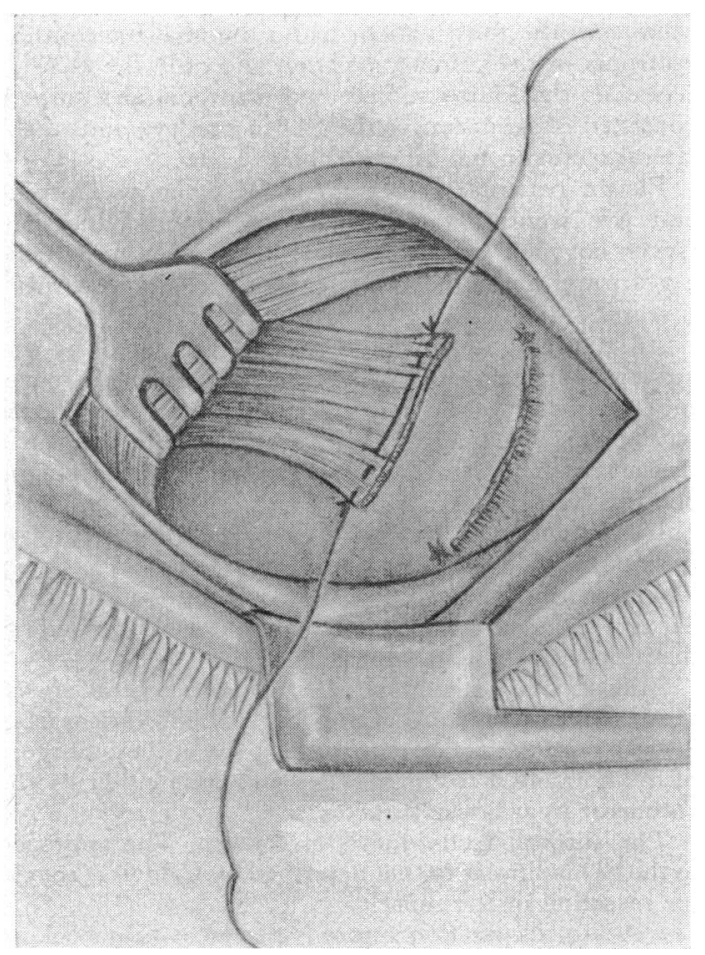

FIG. I Right superior oblique seen from surgeon's position. After the catgut suture was inserted and secured, the tendon was severed. Superior rectus displaced nasally by rectractor to the usual passage of the SO tendon beneath the medial edge of the superior rectus.

II. The recession is measured, using a Castroviejo caliper, over the line connecting the marked point and the one lying at the anterior end of the SO insertion. With the same instrument the recession is also determined from the posterior end of the insertion.

12. After the tendon has been reinserted each incision in Tenon's capsule is closed with one or two 6-0 plain catgut interrupted sutures.

13. A running 6-0 plain catgut mattress suture is used to close the conjunctiva.

The Table shows the preoperative data and the $\mathcal{G}$ amount of surgery performed on each patient.

All patients were re-examined not less than 3 ir months after surgery; the mean duration of follow- $\mathrm{C}$ up was 9 months.

In Cases $\mathrm{I}$ to 12 a Student's $t$ test was performed to compare the mean of the A phenomenon before and after surgery.

\section{Results}

The A phenomenon was fully corrected in five of the 12 patients. In four there was an undercorrection of $9,5,3$, and 2 prism dioptres (PD) respectively. An overcorrection of 3 PD was observed in two patients, and of Io PD in one. The mean correction of the A phenomenon was $26 \mathrm{PD}$.

Of the four patients who had vertical deviations $\stackrel{2}{\vec{P}}$ in the primary position, one was fully corrected, $\frac{\circ}{3}$ one was undercorrected by $5 \mathrm{PD}$ and one overcorrected by $4 \mathrm{PD}$, and in the fourth the deviation? increased by 2 PD.

The postoperative data are shown in the Table.

A Student's $t$ test, which was performed to $\frac{5}{3}$ compare the means of the A phenomenon before and after surgery in Cases $\mathrm{I}$ to $\mathrm{I2}$, showed $t=\hat{\mathrm{g}}$ 9.66 and $P<0.001$ or 0.1 per cent.

Fig. 2 shows Case 12 preoperatively and Fig. 3 읙 the same patient after surgery.

\section{Comments}

In the five patients with $A$ phenomenon fully corrected surgically (Cases $I, 2,7,8$, and 10), the mean of the A phenomenon before surgery was 21 PD. In the four patients undercorrected (Cases $5,9, \mathrm{II}$, and 12 ) the mean was $36 \mathrm{PD}$ and in the $\Phi$ three patients overcorrected (Cases 3,4 , and 6$)^{+}$ the mean was $23 \mathrm{PD}$. Although the total number of $\frac{7}{\vec{*}}$ patients was small the results obtained suggest that $\frac{}{\mathrm{O}}$ in cases of $\mathrm{A}$ phenomenon of $30 \mathrm{PD}$ or more $\mathrm{a} \stackrel{?}{+}$ more generous recession of both SO should be $\stackrel{\varnothing}{\circ}$ tried. In the seven cases of under and overcorrection the mean was not more than Io PD, a tolerable o amount. If the postoperative differences between 

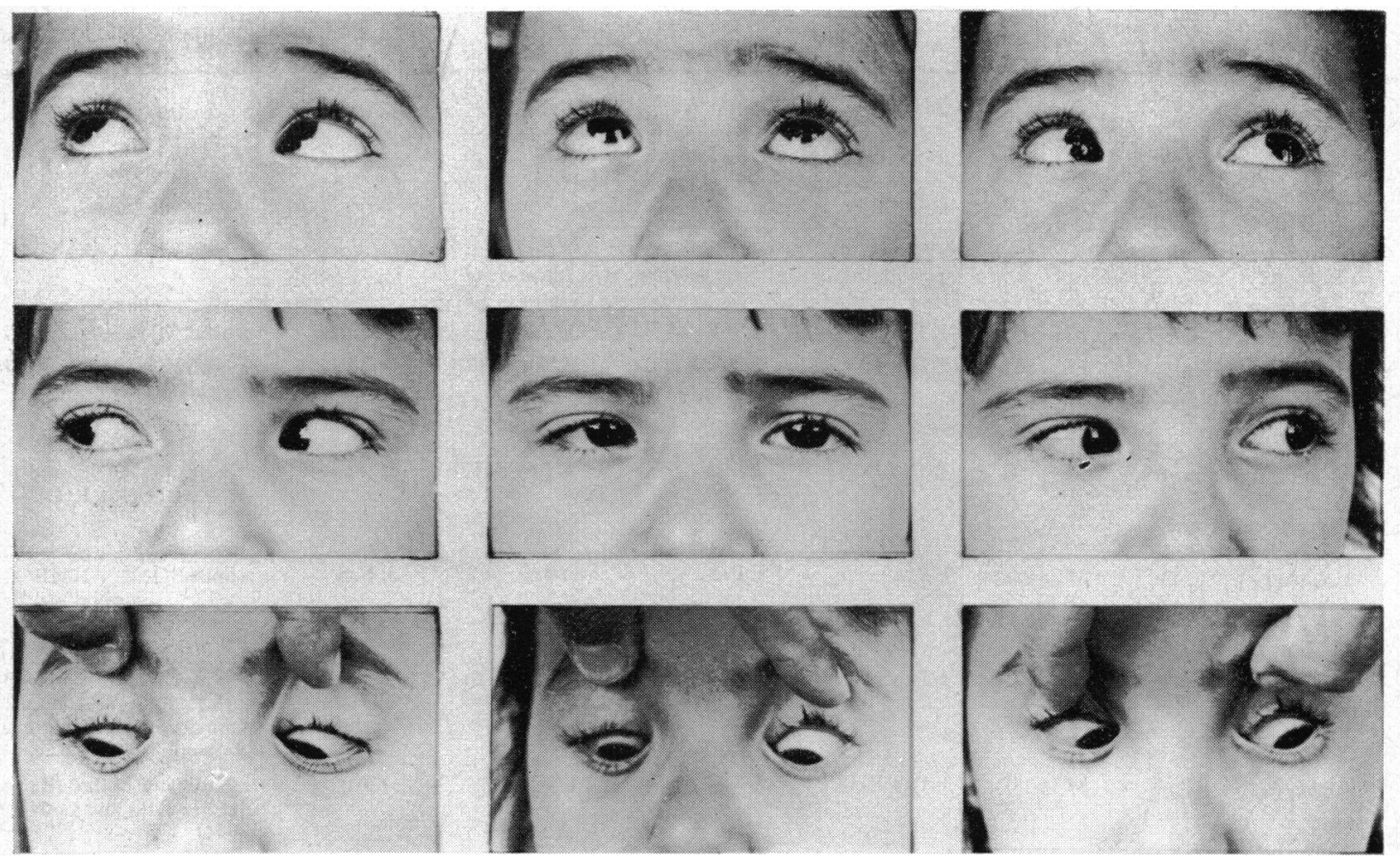

FIG. 2 Binocular rotations of Case 12 preoperatively

the primary position and infraversion are considered-the most important positions in casual seeing-the differences are negligible.

Of the seven patients with $A$ phenomenon and no vertical deviation in the primary position, three (Cases I, 7, and 9) remained so after surgery. Of the other four, one (Case 4) had an intermittent vertical deviation of $5 \mathrm{PD}$, two (Cases 9 and ro) a constant vertical deviation of 4 and 2 PD respectively, and the last (Case II) a dissociated vertical divergence. In general, the vertical imbalance was small and could have been corrected by a prism. In all seven patients the amount of recession of the SO was the same in both eyes.

Of the five patients with $A$ phenomenon and a vertical deviation in the primary position, in one (Case 5) the vertical deviation disappeared, in one (Case 2) it was reduced from 5 to $3 \mathrm{PD}$, and in two (Cases 6 and 12) it was reduced from 2 to I PD. The patient with dissociated vertical divergence (Case 3) had an intermittent left hypertropia after surgery. In all but one of these five patients, one SO was recessed more than the other.

Of the four patients with a vertical deviation in the primary position, one (Case 13 ) also presented an $\mathrm{A}$ phenomenon and this was fully corrected with a recession of one $\mathrm{SO}$ and a recession-resection of the homolateral horizontal rectus muscles.

In Cases 13 and 14, the SO that had not been operated on became overactive after surgery, a fact often observed after unilateral recession of the inferior oblique.

Case 16 was a total failure, probably because of preoperative misjudgement. Simultaneous recession of the contralateral inferior oblique or surgery on a vertical rectus muscle might have had a better result.

Of the $28 \mathrm{SO}$ submitted to recession, only three showed a slight underaction on binocular rotations postoperatively. In one (Case 3) the SO was recessed $10 \mathrm{~mm}$, in the second (Case 13 ) $8 \mathrm{~mm}$, and in the last (Case 15) $9 \mathrm{~mm}$. Recession of the SO within the limits established in this series is thus seldom responsible for a postoperative underaction. In 15 eyes (Cases $I-2$ and $4-12$ ) the action was normalized and in ro eyes (Cases $1-3,7-11$, 14 and 16) some overaction persisted.

Some underaction of the inferior oblique on binocular rotations was noticed preoperatively in 25 of the 28 eyes operated. In six eyes (Cases 7, 8 , 10, 12, and 14) some underaction persisted after surgery, in 12 (Cases 2, 3, 5, 6, 9, 10, 12, and 15) the action became normal, and in seven (Cases $7,8,9,11$, and 13 ) there was a slight overaction.

Head tilting or other unnatural attitudes were not observed postoperatively in this series.

In the only patient with exotropia and A pheno. menon (Case $\mathrm{I}$ ) the deviation in the primary posi- 
Table Preoperative data, amị

\begin{tabular}{|c|c|c|c|c|c|c|c|c|c|}
\hline \multirow{4}{*}{ Case } & \multirow{4}{*}{ No. } & \multirow{4}{*}{$\begin{array}{l}\text { Age } \\
(y r, \\
m t h)\end{array}$} & \multirow{4}{*}{ Sex } & \multirow{4}{*}{ Race } & \multicolumn{3}{|l|}{ Preoperative } & \multirow{4}{*}{ Near } & \multirow{4}{*}{ Binocular rotations } \\
\hline & & & & & Prism-and-cover $n$ & measurements & & & \\
\hline & & & & & \multicolumn{3}{|l|}{ Distance } & & \\
\hline & & & & & $\begin{array}{l}\text { Primary } \\
\text { position }\end{array}$ & Supraversion & Infraversion & & \\
\hline $\mathbf{I}$ & 754855 & 9,8 & $\mathbf{F}$ & $\mathbf{C}$ & XT 18 & XT 8 & XT 25 & XT 16 & +2 both MR and both SO $\overrightarrow{\vec{a}}$ \\
\hline 2 & 1015542 & 12,4 & $\mathbf{F}$ & $\mathbf{C}$ & ET80 LHT 5 & ET80 LHT5 & ET $_{55}$ LHT $_{5}$ & $\begin{array}{l}\text { ET80 } \\
\text { LHT7 }\end{array}$ & $\begin{array}{l}\text { + I both SO; + } 3 \text { both MR; } \bar{\omega} \\
\text {-2 both IO } \\
\text { 음. } \\
\dot{u}\end{array}$ \\
\hline 3 & 15721 & $I 1,8$ & $\mathbf{M}$ & $\mathbf{C}$ & $\mathrm{ET}_{3} 0 \mathrm{DVD}$ & $\mathbf{E T}_{40}$ & ETIo RHT8 & ET25 & $\begin{array}{l}+ \text { I LSO; + } 2 \text { RSO and both } \\
\text { MR;-I LIO; -2 RIO }\end{array}$ \\
\hline 4 & 913844 & 6,11 & $\mathbf{M}$ & $\mathbf{C}$ & ETI4 $_{14}$ & ETI8 & ortho & ET18 & + 2 both SO; + 3 RMR + 4 ل્ \\
\hline 5 & 525629 & 17,10 & $\mathbf{F}$ & $\mathbf{C}$ & $\mathrm{ET}_{4} \circ \mathrm{LHT}_{5}$ & $\mathbf{E T}_{4} 8$ & $\mathrm{ET}_{4}$ LHTIO & $\begin{array}{l}\mathrm{ET}_{4}{ }^{\circ} \\
\mathrm{LHT}_{3}\end{array}$ & 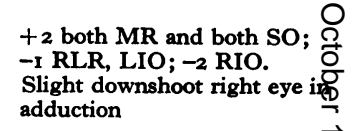 \\
\hline 6 & 981436 & 4,9 & $\mathbf{M}$ & $\mathbf{C}$ & $\mathrm{ET}_{25}$ RHT2 & ET25 LHT2 & ET2 & $\mathrm{ET}_{35}$ & $\begin{array}{l}\text { + I RSO and both MR; +2 } \overrightarrow{0} \\
\text { LSO; }-1 \text { LIO and both LR; } \\
-2 \text { RIO }\end{array}$ \\
\hline 7 & 16248 & 4,6 & $\mathbf{M}$ & C & ET23 $_{2}$ & ET25 & ET8 & ET2I & $\begin{array}{l}\text { + I both SO; + } 3 \text { both MR; } \\
\text {-I RLR; -2 both IO }\end{array}$ \\
\hline 8 & 16207 & 4,2 & $\mathbf{F}$ & C & ET20 & ET20 & ET6 & ETI6 & 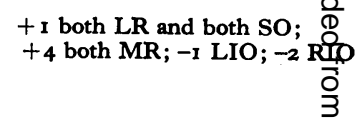 \\
\hline 9 & 1054107 & 13,0 & $\mathbf{M}$ & $\mathbf{C}$ & $\mathrm{ET}_{3} 8$ & $\mathrm{ET}_{47}$ & ortho & $\mathrm{ET}_{3} 8$ & $\begin{array}{l}\text { +2 both SO; }+3 \text { both MR; } \frac{J}{\partial} \\
-1 \text { LIO; }-2 \text { RIO. Slight } \\
\text { downshoot both eyes in adductio }\end{array}$ \\
\hline 10 & 1024312 & 9,6 & $\mathbf{F}$ & C & $\mathrm{ET}_{45}$ & ET $_{54}$ & ET20 & ET60 & $\begin{array}{l}\text { +1 LMR and both SO; + } 3 \text { 응. } \\
\text { RMR; -1 RIO; -2 LIO }\end{array}$ \\
\hline II & 901242 & 6,2 & $\mathbf{M}$ & C & ET $_{45}$ & ET $_{48}$ & ETI2 DVD $_{12}$ & ET $_{56}$ & $\begin{array}{l}\text { + I both SO; + } 3 \text { both MR; } \\
\text { - I LIO; }-2 \text { RIO. Slight down } \\
\text { shoot both eyes in adduction }\end{array}$ \\
\hline 12 & 1063076 & 5,7 & F & $\mathbf{C}$ & $E_{23} L_{2 H T}$ & $\mathrm{ET}_{35} \mathrm{LHT}_{2}$ & ET1 $6_{16}$ & $\mathrm{ET}_{3} 8$ & $\begin{array}{l}\text { + I RLR and both SO; +2 } \frac{D}{O} \\
\text { RMR; + } 3 \text { LMR; -1 LIO: } \\
-2 \text { RIO }\end{array}$ \\
\hline 13 & 763749 & 8, II & $\mathbf{M}$ & $\mathbf{C}$ & ETI8 LHTIo & ETı8 LHT6 & LHT $_{5}$ & $\begin{array}{l}\text { ET20 } \\
\text { LHT10 }\end{array}$ & $\begin{array}{l}\text { +2 RMR, RSO; + } 3 \text { LMR; } \\
\text {-1 LIO; -2 RIO }\end{array}$ \\
\hline 14 & 15944 & 10,0 & $\mathbf{F}$ & $\mathbf{C}$ & $E(T)_{2} R H(T) 10$ & $\mathrm{E}(\mathrm{T})_{4} \mathrm{RH}(\mathrm{T}) 6$ & $\mathbf{R H T}_{20}$ & RHT20 & 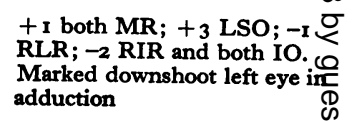 \\
\hline 15 & 14988 & 9,5 & $\mathbf{F}$ & $\mathbf{C}$ & $\mathrm{XT}_{12} \mathrm{RHT}_{12}$ & $\mathrm{X}(\mathrm{T}) 6 \mathrm{RH}(\mathrm{T}) \mathbf{9}$ & XT4 $_{4}$ RHT8 & $\mathrm{RHT}_{7}$ & $\begin{array}{l}\text { + I RMR, RIO, RSO; +2 } \\
\text { LMR, LSO; - 2 LIO. Moderate } \\
\text { downshoot left eye in adduction }\end{array}$ \\
\hline 16 & 1012245 & 10,5 & $\mathbf{F}$ & $\mathbf{C}$ & ET23 $_{23}$ LHT $_{4}$ & $\mathrm{ET}_{28} \mathrm{LHT}_{7}$ & ET25 $_{2 H T}$ LH $_{4}$ & $\begin{array}{l}\text { ET25 }_{14} \\
\text { LHTT }_{14}\end{array}$ & $\begin{array}{l}\text { + I RMR; + } 2 \text { LMR, RSO; } \bar{\Phi} \\
\text {-2 both LR. Slight downshoof } \\
\text { right eye in adduction. Slight } \\
\text { upshoot left eye in adduction }\end{array}$ \\
\hline
\end{tabular}

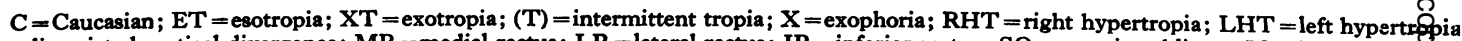
$\mathrm{DVD}=$ dissociated vertical divergence; $M R=$ medial rectus; $L R=$ lateral rectus; $I R=$ inferior rectus; $S O=$ superior oblique; $I O=$ inferior obligue 


\begin{tabular}{|c|c|c|c|c|c|c|c|}
\hline \multirow{4}{*}{ rgery } & \multicolumn{3}{|c|}{ Postoperative } & \multirow{4}{*}{ Near } & \multirow{4}{*}{ Binocular rotations } & \multirow{4}{*}{$\begin{array}{l}\text { Correction } \\
\text { of } A \\
\text { phenomenon } \\
\text { (prism } D)\end{array}$} & \multirow{4}{*}{$\begin{array}{l}\text { Follow- } \\
\text { up } \\
\text { (mth) }\end{array}$} \\
\hline & \multicolumn{3}{|c|}{ Prism-and-cover measurements } & & & & \\
\hline & \multicolumn{3}{|l|}{ Distance } & & & & \\
\hline & $\begin{array}{l}\text { Primary } \\
\text { position }\end{array}$ & Supraversion & Infraversion & & & & \\
\hline th eyes recession SO $9 \mathrm{~mm}$ & ortho & $\mathbf{X I}_{\mathbf{I}}$ & $\mathbf{X} \mathbf{I}$ & LHTr & + I LSO; + 2 both MR; -I LLR & 17 & 15 \\
\hline $\begin{array}{l}\text { ght eye recession MR } 5 \mathrm{~mm} \text {; } \\
\text { lection LR ro mm. Recession } \\
\text { ) } 9 \mathrm{~mm} \text {. Left eye recession } \\
\text { ) } 8 \mathrm{~mm}\end{array}$ & $\begin{array}{l}\mathrm{ET}_{45} \\
\mathrm{LHT}_{3}\end{array}$ & $\begin{array}{l}\mathrm{ET}_{45} \\
\mathrm{LHT}_{3}\end{array}$ & $\begin{array}{l}\mathrm{ET}_{45} \\
\mathrm{LHT}_{3}\end{array}$ & $\begin{array}{l}\mathrm{ET}_{45} \\
\mathrm{LHT}_{3}\end{array}$ & $\begin{array}{l}\text { + I RMR, RSO; + } 3 \text { RLR, } \\
\text { LMR; -I LLR }\end{array}$ & 25 & 6 \\
\hline $\begin{array}{l}\text { ght eye recession MR } 5 \mathrm{~mm} \text {; } \\
\text { section LR } 8 \mathrm{~mm} \text {. Recession } \\
\text { ) } 8 \mathrm{~mm} \text {. Left eye recession } \\
\text { 10 } \mathrm{mm}\end{array}$ & $\mathbf{L H}(\mathbf{T}) \mathbf{r}$ & $\mathrm{LH}(\mathrm{T})_{4}$ & $\begin{array}{l}\mathbf{E T}_{3} \\
\mathrm{LHT}_{3}\end{array}$ & ortho & $\begin{array}{l}\text { + } 1 \text { RLR, LMR; + } 2 \text { RSO; } \\
\text { - I RMR, LLR, LSO, RSR }\end{array}$ & 33 & 14 \\
\hline $\begin{array}{l}\text { ght eye recession SO } 10 \mathrm{~mm} \text {. } \\
\text { sft eye recession MR } 4 \mathrm{~mm} \text {; } \\
\text { 3ection LR } 5 \mathrm{~mm} \text {. Recession } \\
\text { I0 } \mathrm{mm}\end{array}$ & $\begin{array}{l}\mathbf{E}(\mathrm{T})_{2} \\
\mathrm{RH}(\mathrm{T})_{5}\end{array}$ & $\begin{array}{l}\mathrm{E}(\mathrm{T})_{3} \\
\mathrm{RH}(\mathrm{T})_{4}\end{array}$ & $\begin{array}{l}\mathrm{E}(\mathrm{T}) 6 \\
\mathrm{RH}(\mathrm{T}) 4\end{array}$ & $\begin{array}{l}\mathbf{E}(\mathrm{T})_{\mathbf{r}} \\
\mathbf{R H}(\mathrm{T})_{5}\end{array}$ & $\begin{array}{l}\text { + I RIO, LMR; + } 2 \text { LLR, } \\
\text { RMR }\end{array}$ & 21 & 16 \\
\hline $\begin{array}{l}\text { ght eye recession MR } 5 \mathrm{~mm} \text {; } \\
\text { section LR } 8 \mathrm{~mm} \text {. Recession } \\
\text { J 10 } \mathrm{mm} \text {. Left eye recession } \\
\text { J } 10 \mathrm{~mm}\end{array}$ & XTr4 & XTro & $\mathbf{X T r 2}$ & XTi6 & $\begin{array}{l}\text { + I LMR; -I both IR; } \\
\text {-2 RMR }\end{array}$ & 42 & 7 \\
\hline $\begin{array}{l}\text { ght eye recession MR } 4 \mathrm{~mm} \text {; } \\
\text { section LR } 6 \mathrm{~mm} \text {. Recession } \\
\text { I I } \mathrm{mm} \text {. Left eye recession } \\
\text { I I } \mathrm{mm}\end{array}$ & $\begin{array}{l}\text { ETr2 } \\
\text { RHTI }\end{array}$ & $\begin{array}{l}\text { ET8 } \\
\text { LHT2 }\end{array}$ & ETr8 & ETr4 & + I RMR; -I both LR & 33 & 8 \\
\hline $\begin{array}{l}\text { ght eye recession MR } 4 \mathrm{~mm} \text {; } \\
\text { section RL } 5.5 \mathrm{~mm} \text {. Recession } \\
\text { J } 10 \mathrm{~mm} \text {. Left eye recession } \\
\text { I0 } \mathrm{mm}\end{array}$ & ortho & ortho & ortho & $\mathbf{E}(\mathbf{T})_{2}$ & $\begin{array}{l}\text { + I RMR, RLR, RSO, LIO; } \\
\text { + } 2 \text { LMR; -I RIO }\end{array}$ & 17 & II \\
\hline $\begin{array}{l}\text { fft eye recession MR } 4 \mathrm{~mm} \text {; } \\
\text { section } \mathrm{RL} 4.5 \mathrm{~mm} \text {. Recession } \\
\text { J 10 } \mathrm{mm} \text {. Right eye recession } \\
\text { J } 10 \mathrm{~mm}\end{array}$ & $\mathbf{L H T}_{4}$ & ortho & ortho & $\begin{array}{l}\mathrm{ET}_{4} \\
\mathrm{LHT}_{3}\end{array}$ & $\begin{array}{l}\text { + I LIO; + } 2 \text { LLR, LMR; } \\
\text { + } 3 \text { RSO; + } 4 \text { RMR; -1 RIO }\end{array}$ & 14 & 4 \\
\hline $\begin{array}{l}\text { sft eye recession MR } 5 \mathrm{~mm} \text {; } \\
\text { section LR } 9 \mathrm{~mm} \text {. Recession } \\
\text { J } 12 \mathrm{~mm} \text {. Right eye recession } \\
\text { J } 12 \mathrm{~mm}\end{array}$ & $\mathbf{E}_{\mathbf{r}}$ & $\begin{array}{l}\text { ETro } \\
\text { RHTr }\end{array}$ & $\mathbf{E}_{\mathbf{I}}$ & $\mathbf{X} \mathbf{r}$ & $\begin{array}{l}\text { + I LIO, LSO; + } 2 \text { RMR; } \\
\text {-I RLR. Slight downshoot } \\
\text { both eyes in adduction }\end{array}$ & 38 & 3 \\
\hline $\begin{array}{l}\text { ight eye recession MR } 5 \mathrm{~mm} \text {; } \\
\text { section LR } 9 \mathrm{~mm} \text {. Recession } \\
\text { J I } \mathrm{mm} \text {. Left eye recession } \\
\text { J I } \mathrm{mm}\end{array}$ & $\begin{array}{l}\text { ETro } \\
\text { RHT2 }\end{array}$ & $\begin{array}{l}\text { ET12 } \\
\text { RHT2 }\end{array}$ & ET12 & $\begin{array}{l}\text { ETro } \\
\text { RHT2 }\end{array}$ & $\begin{array}{l}\text { + I RSO; + } 2 \text { LMR; - I RMR, } \\
\text { RIO. Slight downshoot left } \\
\text { eye in adduction }\end{array}$ & 34 & 8 \\
\hline $\begin{array}{l}\text { zft eye recession MR } 5 \mathrm{~mm} \text {; } \\
\text { section LR } 9 \mathrm{~mm} \text {. Recession } \\
\text { I I mm. Right eye recession } \\
\text { I I mm }\end{array}$ & $\begin{array}{l}\text { ET5 } \\
\text { DVD }\end{array}$ & ET5 & ortho & $\mathbf{E T}_{3}$ & $\begin{array}{l}\text { + I LLR, RSO and both Io; } \\
\text { + } 2 \text { RMR. Slight downshoot } \\
\text { right eye in adduction }\end{array}$ & $3 \mathbf{I}$ & 5 \\
\hline $\begin{array}{l}\text { eft eye recession MR } 4 \mathrm{~mm} \text {; } \\
\text { section LR } 5.5 \mathrm{~mm} \text {. Recession } \\
\text { J II mm. Right eye recession } \\
\text { J } 12 \mathrm{~mm} \text {. }\end{array}$ & $\begin{array}{l}\mathbf{X}(\mathbf{T})_{\mathbf{r}} \\
\mathbf{L H}(\mathbf{T})_{\mathbf{r}}\end{array}$ & $\begin{array}{l}\text { ET3 }_{3} \\
\text { LHTI }\end{array}$ & ortho & $\begin{array}{l}\mathrm{ET}_{4} \\
\mathrm{LH}(\mathrm{T})_{\mathbf{I}}\end{array}$ & $\begin{array}{l}\text { + I LMR and both LR; } \\
\text {-I RIO }\end{array}$ & 16 & 3 \\
\hline $\begin{array}{l}\text { ight eye recession MR } 4 \mathrm{~mm} \text {; } \\
\text { section LR } 5 \mathrm{~mm} \text {. Recession } \\
\text { ว } 8 \mathrm{~mm}\end{array}$ & $\mathbf{R H T}_{4}$ & RHT2 & $\mathrm{RHT}_{3}$ & RHT7 $_{7}$ & $\begin{array}{l}\text { + I RIO, RLR; + } 2 \text { LIO, } \\
\text { LSO; -I RMR, RSO }\end{array}$ & 18 & 5 \\
\hline eft eye recession $\mathrm{SO}$ ro $\mathrm{mm}$ & RHT5 $_{5}$ & $\begin{array}{l}\text { ETI } \\
\text { RH'T4 }\end{array}$ & RHT2 & $\mathrm{RHT}_{4}$ & $\begin{array}{l}\text { + I both MR; + } 2 \text { both SO; } \\
\text { - I both LR and both IO. } \\
\text { Moderate downshoot left eye } \\
\text { in adduction }\end{array}$ & 一 & 19 \\
\hline $\begin{array}{l}\text { ight eye recession LR } 6.5 \mathrm{~mm} \text {. } \\
\text { eft eye recession SO } 9 \mathrm{~mm}\end{array}$ & $\mathbf{E T}_{2}$ & ortho & $\mathbf{E T}_{4}$ & ET6 & $\begin{array}{l}\text { + I RSO and both MR; } \\
\text { - I RLR, LSO }\end{array}$ & 一 & 17 \\
\hline $\begin{array}{l}\text { ight eye recession } \mathrm{MR}_{4} \mathrm{~mm} \text {; } \\
\text { section LR } 6 \mathrm{~mm} \text {. Recession } \\
\text { I } 12 \mathrm{~mm}\end{array}$ & LHTI6 & LHTI4 & LHTI6 & $\begin{array}{l}\mathrm{ET}_{4} \\
\mathrm{LHT}_{18}\end{array}$ & $\begin{array}{l}\text { + I LMR, RSO; -I RMR, } \\
\text { RLR, LSO; -2 LLR }\end{array}$ & 一 & 3 \\
\hline
\end{tabular}



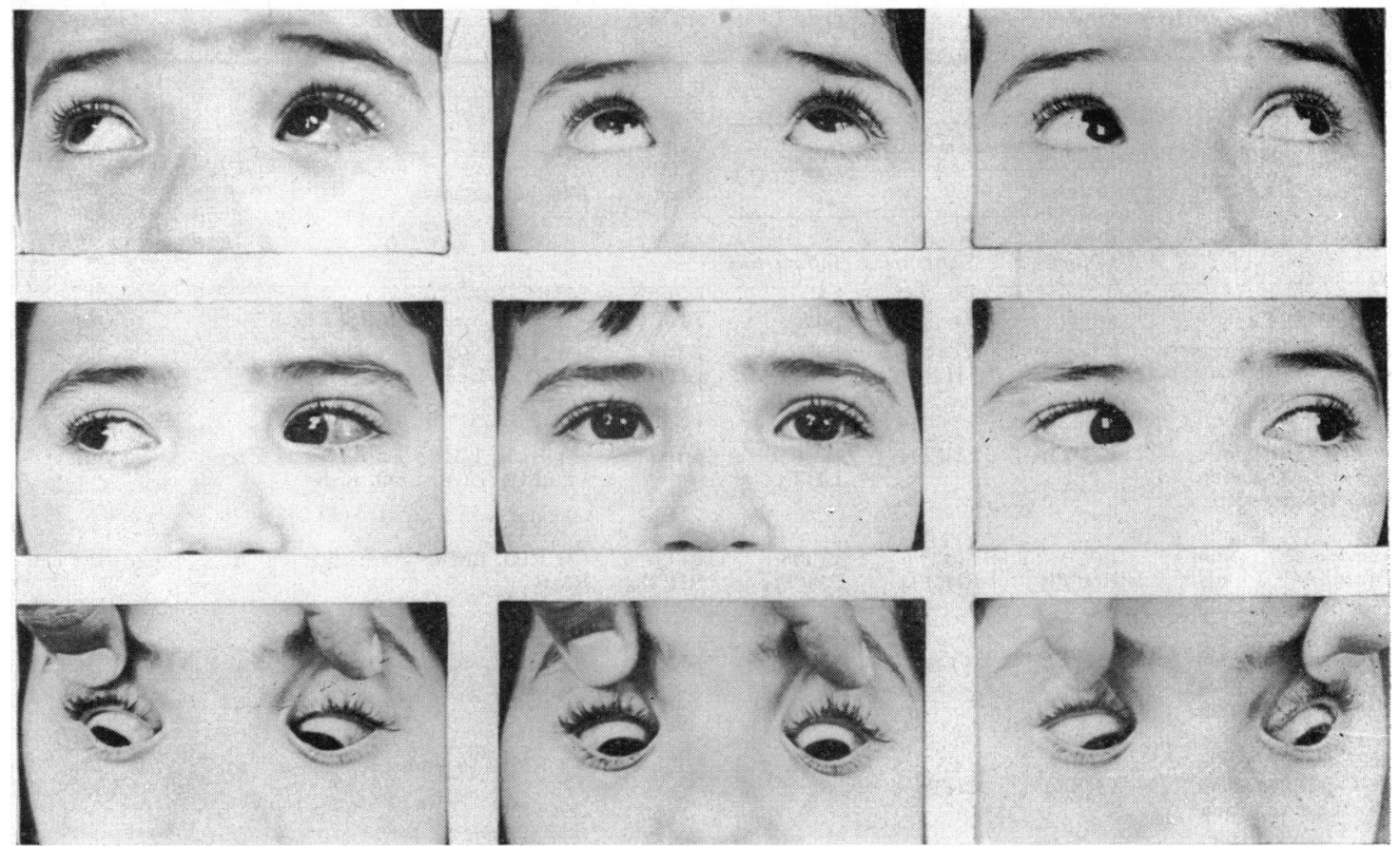

FIG. 3 Binocular rotations of Case 12 postoperatively

tion was fully corrected by a bilateral recession of the SO. A reduction of the angle was also observed by Ciancia and Prieto-Diaz (1970) in two exotropic patients with A phenomenon. Two patients with esotropia and A phenomenon were noticed to have an increase of the deviation in the primary position after a bilateral recession of the SO.

An inability to raise the adducted eye, as with the superior oblique tendon sheath syndrome, was not observed postoperatively in any of the 28 eyes. This suggests that recession of the SO is a safe procedure as far as this complication is concerned, and the adherence syndrome of the superior rectus to the SO (Johnson, 1950).

Prieto-Diaz in $197 \mathrm{r}$ reported a complication in cases of recession of the SO. This was a limitation of depression in abduction or an underaction of the inferior rectus. He attributed this complication to a change in the action of the SO after recession, this muscle becoming both an adductor and an elevator.

A second complication described by Prieto-Diaz in 1974 was an overconvergence on looking down. As neither complication was observed in many cases, he felt that a change in the action of the SO could not be the only cause. He observed that these complications were seen in patients in whom surgery was difficult and there was marked local trauma. In two cases of re-operation the $\mathrm{SO}$ and superior rectus were adherent, with abundant local scarring.
Prieto-Diaz in 1974 proposed a change in technique, using a conjunctival incision $10 \mathrm{~mm}$ from the limbus instead of a limbal incision, and an approach to the SO from the nasal side of the superior rectus, and re-insertion slightly anterior to the equator. He reported no evaluation of the operated patients.

In the 28 eyes operated in this series a uniform technique was followed. After a relatively long conjunctival incision, Tenon's capsule was opened parallel to both margins of the superior rectus. This allowed an easy engagement of this muscle and approach to the SO. After recession, each incision in Tenon's capsule was closed with plain catgut interrupted sutures and a running mattress suture of the same material was used to close the conjunctiva. The technique, described under Tenon's capsule, may explain the absence of complications in this series.

Neither a limitation of depression in abduction nor an overcovergence on looking down was observed in this series. These good results should encourage further investigation.

Although the number of patients with A phenomenon was not large, the mean correction obtained was satisfactory-namely, 26 PD. Practically the same result was obtained by Ciancia and PrietoDiaz (1970). If it is considered that the A phenomenon is usually aggravated by surgery of the 
horizontal rectus muscles alone, especially in esotropia, a simultaneous recession of both SO seems to be indicated. Future researches will show whether a more generous recession of both SO will offer better results in cases of marked A phenomenon.

The number of patients submitted to unilateral recession of the SO is too small for any conclusions to be drawn.

Tenotomy or tenectomy of the SO is a nongraduated, irreversible form of surgery which is seldom used for the four rectus muscles. Inferior oblique recession seems to offer more advantages than disinsertion, myotomy, or myectomy. Tenotomy or tenectomy of the SO cannot be justified if a more promising graduated surgery is available.

Although no patient had a second operation there is no objection, from a theoretical standpoint, to a re-operation.

The good results obtained by previous authors and in this clinical series indicate that recession of the superior oblique is a useful surgical procedure.

\section{Summary}

Recession of the superior oblique was performed bilaterally in 12 patients with the A phenomenon and unilaterally in four patients with vertical imbalance. The results are discussed.

The author would like to thank Mrs Lúcia Moreira de Oliveira for the drawing; Miss Fiammetta Palazio for the photographs; Clovis K. Takiguti, MD, for the statistical analysis; Miss Ilca Bernardi for the Table; Miss Marina Pires do Rio Caldeira for secretarial help.

\section{References}

CALDEIRA, J. A. F. (1975a) 'Horizontal Binocular Rotations in Children'. Presented at Second Meeting of the International Strabismological Association, Marseilles, 20-25 May 1974. To be published

I (1975b) 'Modification of Surgical Technique for Resection of the Superior Oblique Muscle'. Presented

at Twenty-second International Congress of Ophthalmology, Paris, 26-3I May 1974. To be published CiAnCIA, A. O., and PRIETO-DiaZ, J. (1970) Arch. Oftal. (B. Aires), 45, I93

DUKE-ELDER, S., and WYBAR, K. (1973) 'System of Ophthalmology', vol. 6, pp. 499, 789. Kimpton, London FINK, w. H. (1962) 'Surgery of the Vertical Muscles of the Eye', 2nd ed., p. 374. Thomas, Springfield, Ill. FOSTER, J. (1946) Brit. F. Ophthal., 30, 676

HUGHES, w. L., and BOGART, D. K. (1942) Amer. F. Ophthal., 25, 91 I

JAMPOLSKY, A. (1971) In 'Symposium on Strabismus', p. 34. Mosby, St Louis

JoHnson, L. v. (1950) Arch. Ophthal. (Chicago), 44, 870

PRIETO-DIAZ, J. 'Actas III Congreso del Consejo Latinoamericano de Estrabismo'. Mar del Plata, 3-6 noviembre 1971. Not published

'Retroceso del Oblicuo Superior'. Presented at the 'IV Congreso del Consejo Latinoamericano de

Estrabismo', Mexico, DF, 12-16 May 1974. Not published

StaNWORTH, A. (1968) 'Trans. Ist International Congress Orthoptists', p. 149. Kimpton, London 